\title{
Obstacles in EuRopean Competition LAW ENFORCEMENT: A Potential Solution from Collective Redress
}

\author{
Zygimantas Juska*
}

\begin{abstract}
:
The primary focus of this article is to review the main obstacles in competition law enforcement in the European Union and to investigate how the development of collective redress could effectively facilitate enforcement of EU competition law. Arguably, antitrust enforcement remains sub-optimal due to the insufficient deterrent effect of EU antitrust fines and obstacles facing victims of competition law infringements in bringing damages actions. Central to my work, therefore, is the belief that collective actions constitute an attractive vehicle to solve, or at least diminish, the inefficiencies of antitrust enforcement. The paper explores some options as to how to design collective redress mechanisms in order to influence the ability to bring successful collective claims. This would, in turn, consider the advantages of opt-out collective actions in tackling the issues related to low participation rates, lack of funding and sub-optimal deterrence. From this perspective, the article moves on to propose collective actions as a potential remedy to facilitate access to justice, to deal with a wide range of legal and economic issues and to mitigate dysfunctional compensatory mechanism of $E U$ antitrust enforcement.
\end{abstract}

\section{Keywords:}

Antitrust Fines, Collective Redress, Competition Enforcement, Damages, EU Law.

\section{TABLE OF CONTENTS}

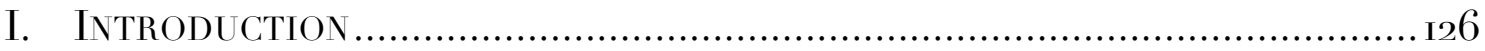

II. The Existing Obstacles and Shortcomings in Competition Law

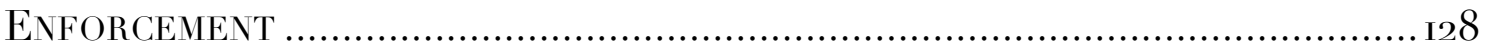

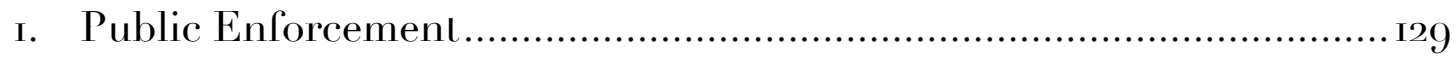

2. Private Enforcement ................................................... 132

3. Tort Remedies and Deterrence in European Private Antitrust

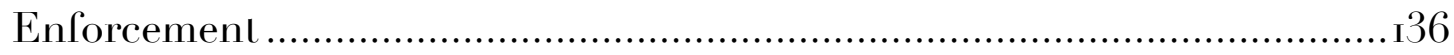

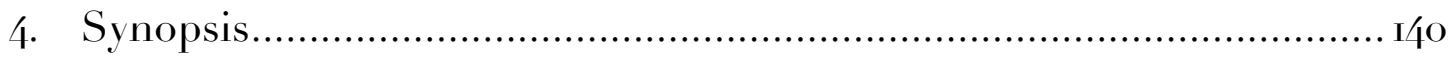

* PhD-candidate at Leiden University, Blue book trainee in the European Commission (DG Comp). The views expressed are purely those of the writer and may not in any circumstances be regarded as stating an official position of the European Commission. 
III. Collective Redress in the European Union: A Potential Vehicle to Mitigate Obstacles in Antitrust Enforcement. I/40

I. Legal Design of Collective Redress Mechanisms .............................. I 1 I

IV. Assessment: Opt-In vs Opt-Out ............................................. I 43

I. Legal Framework for Opt-Out Collective Redress in Antitrust............ I 177

V. Collective Redress as a Potential Remedy to Mitigate Deficiencies of EU Competition LaW Enforcement ................................................. 148

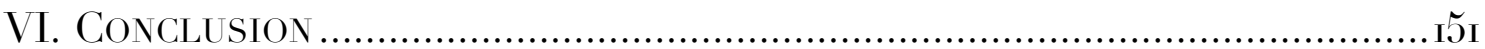

\section{INTRODUCTION}

European competition law is primarily enforced by public authorities the European Commission at the EU level, and the national competition authorities (NCAs) at the national level. However, private enforcement is gaining popularity in Europe. Increased importance attributed to a more favourable legal regime of private enforcement has created more incentives for the European Commission to facilitate damages actions by removing perceived obstacles for victims of anticompetitive conduct. And yet, the discovery of the merits of private antitrust enforcement has culminated in the European Commission eventually concluding a package on private damages actions in antitrust cases in June 20I3. The most important milestone was reached on I7 April 20I4 when the European Parliament overwhelmingly adopted a Directive on antitrust damages actions ${ }^{1}$ for breaches of EU competition law in order to facilitate damages actions in the national courts of the EU's Member States. Once the Directive is approved by the EU Council of Ministers, Member States will have two years to implement the provisions of the Directive in their national legal systems. The Directive seeks to ensure that victims of antitrust infringements can obtain effective compensation and to optimise the interaction between public and private enforcement of EU competition

\footnotetext{
'European Parliament, 'Proposal for a Directive of the European Parliament and of the Council on certain rules governing actions for damages under national law for infringements of the competition law provisions of the Member States and of the European Union' COM (2013) 404 final. Together it was published with: European Commission documents 'Communication from the Commission on quantifying harm in actions for damages based on breaches of article ior or 102 of the Treaty on the functioning of the European Union' [2013] OJ Cı67/o7 and the Staff Working Document 'Practical Guide on quantifying harm in actions for damages based on breaches of article го оr IO2 of the Treaty on the functioning of the European Union' [2013] SWD 205, пr.o6.2013. The law is stated as 7 July 2or4.
} 
rules while at the same ensuring the protection of investigation tools, such as passing on, access to evidence and discovery rules, interaction with leniency. Surprisingly, the collective redress mechanism is not envisaged by this Directive. With a view to remedy this situation, the European Commission published a Recommendation on collective redress $^{2}$ in relation to establishing a European horizontal framework for collective redress mechanisms. It is clear, however, that truly effective compensation may be somewhat limited, if binding collective redress procedures are not included, in particular for consumers who suffered a harm of low value.

In the first place, this paper considers determination of the existing obstacles and shortcomings in competition law enforcement. First, designing the concept of effective deterrence of EU antitrust fines requires consideration of current statistics of the European Commission and building up on the central findings of the law and economics literature. ${ }^{3}$ For the sake of simplicity, the economic calculations are based on the comparison of cartel overcharge and maximum possible fine. Second, it defines the reasons why private parties are not well equipped to enforce their rights. This target is achieved through analysing the common obstacles in cartel damage litigation that apply to all jurisdictions. In addition, this paper also argues that an effective antitrust enforcement should consider the option of framing private damage claims more directly as a means of deterrence. Central to my work, therefore, is the belief that an introduction of a unified system of collective redress, based on opt-out measures, might be an attractive alternative to enhance deterrence and to mitigate deficiencies of competition law enforcement.

\footnotetext{
${ }^{2}$ European Commission, 'Recommendation on common principles for injunctive and compensatory collective redress mechanisms in the Member States concerning violations of rights granted under Union Law' [2013] OJ C3539/3). Together it was published with the "Communication from the Commission to the European Parliament, the Council, the European Economic and Social Committee and the Committee of the Regions "Towards a European Horizontal Framework for Collective Redress"' COM (2013) 40I/2.

${ }^{3}$ M Mariniello, 'Do European Fines Deter Price Fixing?' [2013] Bruegel Policy Review 4; F Smuda, 'Cartel Overcharges and the Deterrent Effect of EU Competition Law' (2012) Centre for European Economic Research No. 12-05o; M Boyer and R Kotchoni 'How Much Do Cartels Typically Overcharge?' (2012) CIRANO Scientific Series i5, Montreal.
} 
The following questions will be clarified in this paper:

1. Which factors can influence the design of successful collective redress?

2. What is the potential added value of a unified model of collective redress based on opt-out measure for improving deterrence and effectiveness in the European competition law?

3. To what extent can collective actions mitigate deficiencies of private enforcement by individual parties?

4. How realistic is it that collective actions can facilitate EU competition law enforcement?

The paper is structured as follows. Section II provides an overview of major obstacles and shortcomings in competition law enforcement. Section III determines the added value of collective redress for improving private damages claims, deterring anti-competitive conduct and enforcing EU competition law. Section IV shows that EU-style collective redress should be formed on an opt-out basis or at least on a hybrid of opt-out/opt-in, while the pure opt-in measure should be avoided. Section V intends to demonstrate that collective redress is a potential remedy to mitigate deficiencies of competition law enforcement. This work ends with a short conclusion summarizing key insights.

\section{The Existing Obstacles and Shortcomings in Competition LAW ENFORCEMENT}

This section provides an overview of the major obstacles of two enforcement models of competition law: on the one hand, public enforcement principally aimed at deterrence, and, on the other hand, private enforcement principally aimed at compensation. By drawing arguments from the current statistics from the European Commission and from the empirical results of law and economics, it is possible to identify first an insufficient deterrent effect of EU antitrust fines and to argue that these fines should be complemented with other measures to increase deterrence, in particular with more effective and more deterrence-oriented approach of damages claims. From this perspective, this chapter develops a better understanding of the reasons why private individuals are not well equipped to enforce their rights. 


\section{Public Enforcement}

In the European Union, the imposition of fines and leniency programs are the principal means of increasing effectiveness of cartel prosecution and deterring infringers from engaging in anticompetitive behaviour. This discussion, however, will be limited to showing the impact of fine spectrum on deterrence while the debate on leniency is not taken into consideration. ${ }^{4}$ The fines guidelines were introduced by the European Commission in June 2oo6. ${ }^{5}$ The major factor which concerns the deterrent effect of the fines imposed by the Commission is to set the fine based on firm's annual sales and the duration of its alleged participation in the cartel. Under this mechanism, the Commission indicates that the maximum fine can only amount to up to $10 \%$ of the infringing undertaking's worldwide turnover of the preceding business year.

At the same time, useful insights regarding the current successes in more effective deterrence may be derived from the current statistics of the European Commission. There is evidence that the amount of fines imposed on convicted cartels has dramatically increased in the recent years. From r99o up until March 20I4, the European Commission imposed fines totalling 22.02 billion euros on companies engaged in

\footnotetext{
${ }^{4}$ This article intends to demonstrate that the major obstacle in EU competition law enforcement relates to insufficient effect of EU antitrust fines. Although the fines are already high, they do not effectively deter infringers from engaging in anticompetitive behaviour. It should be emphasized that leniency programs proved to be very successful in fighting cartels in the European Union. In essence, the leniency policy offers companies involved in a cartel - which self-report and hand over evidence either total immunity from fines or a reduction of fines which the Commission would have otherwise imposed on them. The current EU leniency policy is set out in the EU Leniency Notice [2006] OJ $\mathrm{C}_{29} 8 / 17$ and continues the work of successful 2002 Leniency Notice [2002] OJ C298/ı7); both of these replaced the less successful ${ }_{199} 6$ Leniency Notice $\left[\mathrm{Ig9}_{6}\right] \mathrm{OJ} \mathrm{C}_{20} \mathrm{O} / 4$ ). This is notably because the 2002 Leniency Notice facilitated conditions for full immunity from fines and set out to grant automatic immunity from fines to the first reporting cartel, while the 2006 Notice introduced the discretionary marker system. Both Leniency notices increased the rate of detection and significantly strengthened the deterrence.

${ }^{5}$ European Commission, 'Guidelines on the Method of Setting Fines Imposed Pursuant to Article 23(2) of Regulation No i/2003' [2006] OJ C2ı/2.
} 
cartel violation within the European Economic Area. ${ }^{6}$ The total amount of fines imposed on convicted cartels rose from 832 million euros over the period I990 - i999 to I2.8 billion euros over the period 2000 - 2009. The increasing trend in fining policy is also evident in the last 4-year period (20IO - 20I4) during which the European Commission gradually fined of the total amount of 8,4 billion euros. Even at their unprecedented high level, the insufficient deterrent effect of the EU antitrust fines should be observed. During the last decade, the number of discovered cartels is increasing tremendously without any indication of slowing down. This is demonstrated by the fact that recently imposed fines are based on the new fine guidelines, which concern the aim for higher fines and thus deterrence. To make the discussion more fruitful, it should be observed that 9 of the top ro fines have been in the last 6 years. As regards the $10 \%$ threshold, it must be borne in mind that this legal maximum was attained in 4 large cases out of $\mathrm{I} 3$ fined in the last decade. ${ }^{7}$ The resulting problem is that the fines calculated by the Commission had to be reduced.

Furthermore, the law and economics literature estimates fine levels to be structurally below the adequate level to achieve optimal fine. ${ }^{8}$ Key parameters for calculating the deterrent effect of current fines are therefore the price increase (cartel overcharge) compared with the maximum possible fine. Relying on the results estimated by Smuda (given the upper limits of fine and probability of detection), the expected fine can sum up to a maximum of $I$ I. $46 \%$ of affected sales per year in comparison with a mean of overcharge rate of 2 I. $9 \% .{ }^{9}$ Under the

${ }_{6}^{6}$ European Commission, 'Cartel Statistics' (last updated I9 March 2014) $<$ http:/ec.europa.eu/competition/cartels/statistics/statistics.pdf $>$ accessed 20 December 20I3. The fine statistics are not adjusted for Court judgments.

7 M Allain, M Boyer, R Kotchoni and J Ponssard, 'Are Cartel Fines Optimal? Theory and Evidence from the European Union' (2013) CIRANO 2013s-24, $2<$ http://papers.ssrn.com/sol3/papers.cfm?abstract_id=2342I8o $>$ accessed пі January 20I4; for further discussion see also A Riley, 'The Modernisation of EU Anti-Cartel Enforcement: Will the Commission Grasp the Opportunity?' CEPS Special Report/January $2010<$ http://aei.pitt.edu/ı/557o/I/Modernisation_Final_e-version.pdf $>$ accessed i8 February 2014.

${ }^{8}$ See for a thorough discussion Mariniello (n 3); Allain, Boyer, Kotchoni and Ponssard (n 7); Boyer and Kotchoni (n 3); Smuda (n 3); JM Connor and RH Lande, 'Cartel Overcharges and Optimal Cartel Fines' (2008) 3 Competition Law and Policy 2203.

${ }^{9}$ Smuda (n 3). To consider whether the collusion outweighs expected punishments author provides the following equation: OvRate $(\mathbf{I}) \cdot($ Pcollusion $\cdot \mathbf{x})<\pi \cdot \gamma($ Pcollusion . 
estimated results, the overcharge rate is higher than the maximum possible fine; also, it demonstrates that the gain from collusion outweighs expected punishments. Furthermore, Connor finds a mean of overcharge rate of 5o.4\% for very successful cartels (so-called 'Connor database'). To that extent, Boyer and Kotchoni amended the Connor database in order to determine more accurate results, whereby the estimation was reduced up to $45.5 \%$. ${ }^{\circ}$ In both scenarios, however, cartels are not deterred from the collusion even if the probability rate would be Iоo\%." Other estimations found that in the period between 200I-2OI2 cartels caused I8.4 billion euros worth of harm to the

$\mathrm{x})$. Here, $\pi$ - the probability of detection, Pcollusion - the price during collusion, $\mathrm{x}-$ the amount of sold goods, OvRate(I) - the average overcharge rate over the entire cartel period, $\gamma$ - maximum possible fine $(30 \%+(25 \%$ : cartel duration). The upper limits of fine and probability of detection is $33 \%(\mathrm{o}, 33)$ while the average duration of cartel is 5,7 years. As such, the average cartel can amount up to of maximum o:33 . $[30 \%+(25 \%: 5,7)]=$ Iг: $46 \%$ in comparison with a mean overcharge rate of $21.9 \%$ of selling price per year.

${ }^{10}$ For further discussion on Connor database and its amendment, see Boyer and Kotchoni (n 8).

"Connor and Lande (n 8) estimate state probabilities of detection ranging between Io-33\% in economic theory, while E Combe, C Monnier and R Legal calculate a range between 12.9 and $13.2 \%$ for the European market (see E Combe, C Monnier and R Legal, 'Cartels: the Probability of Getting Caught in the European Union' (2008) Bruges European Economic Research papers 12). Essentially the probability of detection takes on a major role in estimating the deterrent effect of EU antitrust policy. The magnitude of detection probability guides how the optimal sanction should be structured. This value is of particular importance for directors and/or managers who are willing to join or create a cartel. In addition, public authorities are better suited to design an optimal policy regarding the fight against cartels, if approximate probability rate is known. It seems clear that excluding the choice of detection from the $\mathrm{EU}$ antitrust enforcement would negatively affect the overall discussion on deterrent effect of current fines. This is notably because the determinants of deterrence include: i) the probability of detection ii) price during collusion iii) the amount of sold goods iv) the average overcharge rate. These elements are interchangeable; without one of them, the fine and deterrence estimation is impossible. Particularly, the introduction of leniency programs in the European Union has contributed to reinforce the probability of detection. Given the fact that full immunity is granted only to the first applicant, it causes lack of assurance within the cartel if slight deviations appear from the cartel plan, for instance the 'empty chair example'. For further discussion, see JA Chavez, 'The Carrot and the Stick Approach to Antitrust Enforcement' [2006] Practising Law Institute Corporate Law and Practice Course Handbook Series, May PLI Order No. 8736. 
European Economy, which seems extremely low in comparison with $€_{209}$ billion of the total affected EEA sales. ${ }^{2}$

Perhaps the most obvious solution would be to increase the fines as well as turnover for maximum of $\mathrm{I0} \%$. However, the input received through that increase might undermine the undertakings' ability to pay, thereby inducing undesirable social costs (such as bankruptcy, losses of jobs and lessening competition in the market). ${ }^{13}$ It clearly emerges that current fine levels should be complemented with other measures to enhance deterrence. In fact, a more effective and more deterrence-oriented private enforcement should be considered. This may include a rule similar to the US' trebling of antitrust damages under the Clayton Act $^{1 / 4}$ or opt-out collective redress mechanisms. Before delving into the details of these alternatives towards a more-deterrence-oriented approach, it is both necessary and instructive to review the existing obstacles in private antitrust enforcement.

\section{Private Enforcement}

The Commission estimates that only $25 \%$ of the final cartel and antitrust prohibition decisions taken by the Commission in the period 2006-20I2 were followed by private damages actions. ${ }^{5}$ Moreover, far from reaching all victims, the majority of these actions were brought by large companies or public entities whereas SMEs and consumers normally

\footnotetext{
I2 Mariniello (n 3). The author observes that affected sales include sales by all market members (that is not necessarily cartel members).

${ }^{13} \mathrm{~W}$ Wils, 'Is Criminalization of EU Competition Law the Answer?' (2005) 28 World Competition 2, I48; L Talev, 'What Threats Exist to the Successful Operation of the EU 2006 Leniency Notice?' (2010) unpublished <www.varadinovlaw.com/en/wpcontent/uploads/20I0/ı2/clasf_paper_talev_leniency_final_ıo-o9 20Io.doc $>$ accessed 5 January 20I4.

${ }^{1 / 4}$ The entirety of the Clayton Antitrust Act of 1914 is codified at 15 U.S.C. $\$ \S ~ 12-27$ (2009). Section 4 of the Clayton Act is codified at 15 U.S.C. $§ 15$ (2009). See for a thorough discussion CL Sagers, Examples \& Explanations: Antitrust (Aspen Publishers 20II); RJR Peritz, Competition Policy in America: History, Rhetoric, Law (Oxford University Press 200I).

I็ European Commission, 'Staff Working Document Impact Assessment Report: Damages actions for breach of the EU antitrust rules Accompanying the proposal for a Directive of the European Parliament and of the Council on certain rules governing actions for damages under national law for infringements of the competition law provisions of the Member States and of the European Union' [2013] SWD 203 final, para. 52.
} 
did not engage in legal actions for reparation of their harm. It can thus be stressed that the lack of effective compensation has created a considerable cost for the European consumers and businesses. Simple estimates that the cost of ineffective right to damages (so called 'foregone compensation') for consumers and SMEs from hard-core cartels between 2006 and 2012 is in the range of $25-69$ billion euros. ${ }^{16}$

To enable a better understanding of the shortcomings of private enforcement, this discussion would reveal reasons why private parties are not well equipped to enforce their rights. There are indeed three main obstacles facing victims of competition law infringements in bringing damages actions: (i) cost and (legal) uncertainty, (ii) complexity of causality, and (iii) disclosure rules. Each of these factors will be discussed in turn.

First, it is generally assumed that private individuals will only commence legal actions if they expect a positive cost-benefit ratio. With respect to antitrust damages claims, it is easy to recognize that private parties face large legal costs to start and develop their case, thereby legal proceedings often exceed the expenses of their claims, creating the socalled 'rational apathy' problem. Further complicating the picture, in the European Union there is a predominant 'loser pays' principle. ${ }^{17} \mathrm{~A}$ crucial issue, in this respect, is that the judge applies the 'loser pays' principle on a case-by-case basis, meaning that the final decision is less predictable for the claimants. If the claim is unsuccessful, individual claimants face significant exposure to the other side's costs. ${ }^{\text {I8 }}$ Furthermore, private parties stand isolated against large companies

${ }^{16}$ CE Mosso, 'The Commission's Proposal for a Directive on Antitrust Damages Actions' (Conference on 'Antitrust Damages: the European Commission's proposal', Bruegel, Brussels, 20 June 2013).

${ }^{17}$ The 'loser-pays' principle is the most widely adopted allocation method for legal costs in the EU Member States. According to this principle, the losing party should pay the other party's legal costs (court and lawyers' fees). Although this instrument is an effective safeguard against unmeritorious claims, but it actually exacerbates the problem of funding in private damages actions. The 'loser pays' principle is currently applied in all of the EU Member States, as well this principle is predominant in collective action mechanisms, if presently exist in the State.

${ }^{18}$ P Collins, 'What are the Problems with EC Antitrust Damage Actions in Europe? Does the Private Pillar Require Reinforcement?' (2007) unpublished $<\mathrm{http}: /$ vartotojuteises.lt/content/download/412/2587/file/Philip\%2oCollins\%2oPaper.p df. $>$ accessed Io January 20I4. 
because large and powerful companies have better legal support, resources and broader investigative powers. From this perspective, it should be observed that in less developed and smaller countries, for example in the Eastern Europe, business relations are more formal, meaning that private parties might be afraid to start a lawsuit against powerful firms because of potential retaliation. As regards consumers, they are often unaware that they are being, or have been, harmed by hard-core cartels (price-fixing, quantity limits or bid rigging). Even if consumers are aware of the infringement, the harm caused by pricefixing cases, for example, often produce scattered and low-value damage to a multitude of consumers. As a consequence, only few of them can afford taking a legal action since the expected benefits outweigh the expected costs.

The second characteristic feature of typical private antitrust cases is the fact-intensiveness and confrontation with complex causality assessments, both legal and economic. The principal purpose is to prove the causality between the antitrust infringement and the harm suffered by the claimant. The burden of proof typically lies with the claimant, who has to demonstrate that the infringing conduct has resulted in the damage claimed. This is a daunting task, particularly given that a majority of the Member States require proving causation with near certainty $\left(99.9 \%\right.$ probability). ${ }^{19}$ This burden is even more complicated, given the fact that claimants stand isolated against antitrust violators who generally are much more aware of the infringement. Even if damages actions were followed-on by a previous public antitrust decision, claimants still need to adduce clear evidence of causation and loss to recover damages. ${ }^{20}$ Another issue that concerns assessing causation is the 'but-for' test. The test examines the hypothetical scenario if the infringement of Article IOI or Io2 TFEU had not occurred: the assessment of the position of the injured party with the position in which this party would have been but for antitrust infringement (often referred as 'counterfactual scenario'). Developing an actual counterfactual scenario requires evaluation of how the market evolved without the antitrust infringement. Estimation has to rely on a number of determinants: (i) market context; (ii) type of harm; and (iii)

\footnotetext{
${ }^{19}$ HA Abele, GE Kodek, GK Schaefer, 'Proving Causation in Private Antitrust Cases' (2013) $7 \mathrm{~J}$ of Competition Law \& Economics 4, 848-49.

${ }^{20}$ See for example, case Enrol Coal Services Ltd * English Welsh \& Scottish Railway Ltd [2010] EWCA Civ 2.
} 
types of claimants. Conducting such an analysis requires a thorough understanding of economic variables (such as prices, sales volumes, profits, costs or market shares). This is certainly not an easy task, given the fact that the results rely on many assumptions. ${ }^{21}$ Furthermore, the analysis of causation is an essential element for the quantification of actions for damages. Claimants often face difficulties in quantifying precisely the harm caused by the infringement of the competition law as a result of numerous factors, such as evidentiary obstacles, lack of access to information or robust estimation of damage. ${ }^{22}$ Furthermore, legal provisions for proving damages and causality are too general to be directly applicable to a private antitrust case..$^{23}$ A separate standing issue is that the claimants are put off by the complex economic analysis; something which is a significant burden for private parties. The economics and financial literature has developed a wide array of methods and models for quantifying damages. For example, in the OXERA study prepared for the European Commission, the methods and models are classified into three broad groups: comparator-based, financial-performance-based, and market-structure-based. ${ }^{24}$ For these reasons, it is argued that the whole causation procedure requires more resources and expenses to elaborate legal proceedings than is expected.

\footnotetext{
${ }^{21}$ See for example, Joined Cases C-104/89 and C-37/9o Mulder and others v Council and Commission [2000] ECR I-203. The Court assessed the hypothetical scenario: "the loss of earnings is the result not of a simple mathematical calculation but of an evaluation and assessment of complex economic data. The Court is thus called upon to evaluate economic activities which are of a largely hypothetical nature. Like a national court, it therefore has a broad discretion as to both the figures and the statistical data to be chosen and also, above all, as to the way in which they are to be used to calculate and evaluate the damage', para 79 .

${ }^{22}$ I Lianos, D Geradin, Handbook on European Competition Law: Enforcement and Procedure (Edward Elgar Pub 2013), 255.

${ }^{23}$ Abele, Kodek and Schaefer (n i9), 853.

24 Oxera, Quantifying Antitrust Damages, Study Prepared for the European Commission, December 2009 $<$ http://ec.europa.eu/competition/antitrust/actionsdamages/quantification_study.pdf $>$ accessed i/ July 20I4. According to this study: I) Comparator-based approaches use data from sources that are external to the infringement to estimate the counterfactual (cross-sectional comparisons, time-series comparisons and combination of both models); 2) Financial-analysis-based approaches use financial information on comparator firms and industries, benchmarks for rates of return, and cost information on defendants and claimants to estimate the counterfactual; 3) Marketstructure-based approaches use a combination of theoretical models, assumptions and empirical estimation.
} 
The third characteristic concerns issues related with disclosure rules. As a general rule, much of key evidence is often held exclusively by the allegedly infringing undertakings, making it difficult for a claimant (if aware of the evidence at all) to obtain disclosure of documents. These materials are crucial in successful antitrust damages actions in which infringing conduct tends to be secretive. From the domestic perspective, the rules on disclosure vary between States making it difficult to assess whether and under what conditions the State is willing to give access to documents. In civil law countries (such as Germany, Lithuania or Austria) the rules on disclosure provides only limited access for the plaintiffs to the internal information of the defendants. Contrary to current shift in civil law countries, the disclosure rules in English courts have rigorous disclosure regimes in place, yet it requires parties to disclose documents that may help for claimants to prove the alleged overcharge they paid.

In order to mitigate these deficiencies of private enforcement, the European Parliament eventually adopted the Directive on antitrust damages actions on 17 April 2014. The text was agreed between the European Parliament and the Council during the ordinary legislative procedure. Once the Directive is approved by the EU Council of Ministers, Member States will have two years to implement the provisions of the Directive in their national legal systems. As already pinpointed at in the introduction, from the perspective of consumer protection it is rather disappointing that the adopted text does not include any provisions on collective redress. In the area of antitrust where illegal behaviour may generate scattered and low-value loss to a number of consumers and where the individual proceedings may not be proportionate, the added value of a binding approach on collective redress would be a significant event.

\section{Tort Remedies and Deterrence in European Private Antitrust Enforcement}

This paper argues that effective antitrust enforcement should consider a more active role of private damage claims more directly as a means of deterrence. An effective deterrence - comprising both of public and private enforcement - might guarantee that the antitrust violation never actually occurred. It clearly emerges that preventing anticompetitive conduct is the best way to ensure the welfare of consumers, competitors 
and other market participants. Even if we assume that the Europeans developed a perfect private enforcement system, such a system cannot restore all the social benefits that stem from well-functioning competitive markets and that are lost when competition is lessened or distorted. ${ }^{25}$ Therefore, if there is a conflict between the antitrust objectives, deterrence needs to prevail over compensatory objectives.

However, the Commission observed that the pursued aim of private actions is mainly to serve as a compensatory function, while deterrence is viewed solely as an effect of enhancing public intervention tools. However, it is equally true that if private actions, of both the follow-on and standalone type, do not contribute through further deterrence, they serve the same function as the tort remedies have in national jurisdictions. ${ }^{26}$ Furthermore, regulating tort actions traditionally remains the domain of domestic rules, and the Commission has stressed the alarming importance of the absence of a European Tort Law. More importantly, national tort actions proved to be practically ineffective in European antitrust enforcement. Basedow observes, in this respect, that 'the remedies provided by private law have turned out to be insufficient or even totally inadequate for the protection of competition'. ${ }^{27}$ The matter is that actions in tort cannot have functions other than exclusively the compensatory one. It is necessary to go beyond mere compensation in order to achieve a more deterrence-oriented approach and thus effective antitrust enforcement.

\footnotetext{
${ }^{25}$ P Buccirossi and M Carpagnano, 'Is it Time for the European Union to Legislate in the Field of Collective Redress in Antitrust (and how)?' (2013) 4 Journal of European Competition Law \& Practice I, I3.

${ }^{26}$ E Camilleri, 'A Decade of EU Antitrust Private Enforcement: Chronicle of a Failure Foretold?' (2013) 34 Eur Competition L Rev ı,, 533. The author observes that this situation implies for private law remedies to gain an unprecedented strategic position, in particular the one happens for the tort remedy. Although the current system sets private enforcement at the centre of the stage of antitrust enforcement, but it is seemingly unfit to play such a unprecedented strategic role. For further discussion on tort actions of antitrust enforcement, see F Marcos and A Graels, 'Towards a European Tort Law? Damages Actions for Breach of the EC Antitrust Rules: Harmonising Tort Law through the Back Door?' (2008) i6 Eur Rev of Private L 3; T Ottervanger, 'Designing a balanced system: Damages, Deterrence, Leniency and Litigants' Rights' as cited in M Marquis (ed) 'Perchance to Dream: Well Integrated Public and Private Antitrust Enforcement in the European Union' (2013) European University Institute, I $8<$ http://papers.ssrn.com/sol3/papers.cfm?abstract_id=237I338> accessed i5 July 2or

${ }^{27} \mathrm{~J}$ Basedow, Private enforcement of EC Commission (Kluwer International 2008), I.
} 
One option may include a rule similar to the US' trebling of damages for infringements of antitrust law under the Clayton Act. ${ }^{28}$ Under this system, the successful plaintiffs are able to recover compensatory damages as much as three times of actual damages. As such, both deterrence and compensation functions are effectively pursued. It seems clear that awarding civil plaintiffs treble damages is a fuel for more active litigation in the EU. On this point it ought to be recalled that private damage action is is an economic activity for which funding is crucial to success or failure of any proceedings. Because of the predominance of the 'loser pays' principle in the Member States, feasible alternatives are required so as to incentivize private parties to start a claim. If successful claimants are able to recover compensatory damages as much as three times of actual damages, it definitely acts as an incentive to start a private claim. Furthermore, punitive damages are of particular importance in collective actions, where the total costs for bringing collective damages actions can be extremely high because of the complexity of legal and economic assessments in such cases, the involvement of multiple parties, and the difficulty in allocating the proceeds. ${ }^{29}$

Regarding these factors it should be recalled that the European Commission also previously attempted to introduce double damages (a form of punitive damages) for horizontal cartels in the 2005 Green Paper on damages, but it was severely criticized by the Member States and was no longer included as a proposal in the 2008 White Paper. As a matter of EU jurisprudence, the CJEU acknowledged that the imposition of punitive damages in response to harm caused by antitrust violations would not be contrary to European public order. ${ }^{30}$ Despite the positions taken by the Court, punitive damages still seem to be an alien concept to the European litigation culture. First and foremost, punitive damages

\footnotetext{
${ }^{28}$ The US Supreme Court has repeatedly stated that the private right of action for treble damages under the antitrust laws serves two purposes: compensating injured victims of unlawful conduct and attracting enforcement resources to supplement the government's deterrence-oriented efforts. Further discussion of the treble damages regarding the objectives of compensation and deterrence, see Tex. Indus., Inc. v. Radcliff Materials, Inc., 45ı US 63o, 636 (I98I); Brick Co. v. Illinois, 43і US 720, 746 (1977).

${ }^{29}$ C Leskinen, 'Collective Actions: Rethinking Funding and National Cost Rules' (20іi) 8 CMLR i, 95 .

${ }^{30}$ Joined Cases C-295/04 to 298/04 Vincenzo Manfredi and Others o Lloyd Adriatico Assicurazioni SpA and Others [2006] ECR I-66r9, [97] and [98].
} 
are in conflict with the fundamental principle of damages actions in the $\mathrm{EU}$; that is to compensate for injury actually suffered. ${ }^{3 \mathrm{I}}$ Second, punitive damages are also not in line with the general principles of Civil Law in the Member States, which prevent any unjust enrichment. ${ }^{32}$ Finally, in the United States where punitive damages are a motivating power in private enforcement, damages actions are intended to at least partly substitute for public enforcement actions while in the $\mathrm{EU}$ there is a clear distinction between the roles public and private enforcement. Notably, public enforcement serves the punitive objective-function. This function is pursued through the imposition of fines, which punish the infringers and deter them from breaching the law in the future. Conversely, private enforcement and more specifically damages actions primarily serve the objective of compensation, while deterrence is only seen as a welcome side-effect. It is agreed that punishment and deterrence are not the elements of civil remedies in the EU. For these reasons, punitive damages are generally considered incompatible with the public policy (ordre public). ${ }^{33}$ In addition, the award of punitive damages breaches the fundamental principle of ne bis in idem. ${ }^{34}$

\footnotetext{
${ }^{31}$ The Commission's 2008 White Paper on damages for breach of EU competition law (COM (2008) i65) ruled that all victims of infringements of EC competition law have access to effective redress mechanisms so that they can be fully compensated for the harm they suffered. Full compensation is, therefore, the first and foremost guiding principle. The Commission welcomes the confirmation by the Court of Justice of the types of harm for which victims of antitrust infringements should be able to obtain compensation. In the Manfredi case (n 3o), the Court emphasised that victims must, as a minimum, receive full compensation of the real value of the loss suffered. The entitlement to full compensation therefore extends not only to the actual loss due to an anti-competitive price increase, but also to the loss of profit as a result of any reduction in sales and encompasses a right to interest, $\left[9^{5}\right]$ and $[97]$.

${ }^{32}$ The Court of Justice decided, in Case C-47/07 P, Masdar (UK) Ltd o Commission of the European Communities [2008] ECR I-976I, that a person who has suffered a loss which increases the wealth of another person without there being any legal basis for that enrichment has the right, as a general rule, to restitution from the person enriched, up to the amount of the loss. Legal redress for unjust enrichment, as provided for in the majority of national legal systems, is not necessarily conditional upon unlawfulness or fault with regard to the defendant's conduct [4447]. As regards national jurisdictions, see, for instance, sec. 812-822 of German Civil Code; sec. 6.242 of Lithuanian Civil Code; sec. II/5 and II58 of Spanish Civil Code.

${ }^{33}$ On December ${ }^{\text {st }}$ 2oro The French Court de Cassation in case, Schlenzka o SA Fountain Pajot, case $n^{\circ}$ Iogo, held that 'an award of punitive damages is not, per se, contrary to public policy, adding however that this principle does not apply when
} 


\section{Synopsis}

In formulating the concept of imperfect antitrust enforcement, it has been observed that current fine levels are sub-optimal to ensure deterrence. A logical implication of this remark would seem to be that since European antitrust follow-on actions constitute the tort remedies and given that the recovery of punitive damages is problematic in the $\mathrm{EU}$, the unified model of collective redress is the most realistic alternative for a more deterrence-oriented approach. Another problem concerns procedural and legal obstacles due to which private parties are not well equipped to enforce their rights. From this perspective, it seems that collective redress is also a potential remedy to mitigate the deficiencies of private antitrust enforcement by individual parties.

\section{Collective Redress in the European Union: A Potential Vehicle to Mitigate OBstacles in Antitrust ENForCEMENT}

This section aims to provide arguments as to why collective redress is an attractive alternative to solve, or at least diminish, the inefficiencies of antitrust enforcement. First, it explains the particular milestones that affect the ability to bring successful collective claim. Furthermore, it aims to provide an initial characterization of the ability of collective claims to act as an incentive for deterrence. Finally, it demonstrates that collective redress is a potential remedy to mitigate deficiencies of private antitrust enforcement by individual parties.

the amount awarded is disproportionate with regard to the damage sustained and the debtor's breach of his contractual obligations'. Taking the example of prohibition of punitive damages in Germany, see RA Schütze, 'The Recognition and Enforcement of American Civil Judgments Containing Punitive Damages in the Federal Republic of Germany' (1989) U Pennsylvania J of Int Business L ir(3).

${ }^{34}$ The legal principle of ne bis in idem restricts the possibility of a defendant being prosecuted repeatedly for the same cause of action. The English Court in case, Devenish etc. v. Sanofi-Aventis etc., [2007] EWHC $2394(\mathrm{Ch})$, held that the principle of ne bis in idem precludes the award of exemplary or punitive damages. For further discussion, see W Wils, 'The Relationship between Public Antitrust Enforcement and Private Actions for Damages' (2009) World Competition 32(I), 2I-22; W Wils, 'The Principle of $\mathrm{Ne}$ Bis in Idem in EC Antitrust Enforcement: A Legal and Economic Analysis' (2003) 26 World Competition, i3 I. 


\section{Legal Design of Collective Redress Mechanisms}

From the European standpoint, the last few years have seen rapid developments in the area of collective redress in the Member States. Currently, twenty states have their own collective redress schemes. ${ }^{35}$ However, even where it is available, the implemented systems have not been very successful because the number of collective actions is very low. Based on the results provided by the Lear Study, ${ }^{36}$ to date there have been collective redress cases for antitrust infringements in only six countries while the trial stage has been reached only in Austria, Spain, France, and the UK. It emerges clearly that the ability to bring a successful collective claim depends on the type of collective actions introduced, particularly whether it provides sufficient incentives to bring collective action and possibilities for funding.

The first and foremost feature in antitrust regards how precisely claimants need to be identified for an action before the court: on an optin or an opt-out basis. Most of the countries have adopted opt-in mechanisms which require explicit consent from the victims to join the action. The major reason that inspired the Member States to choose an opt-in model is that there are advantages of limiting the risk of unmeritorious actions. Furthermore, an opt-in measure respects an individual right to be part of the litigation or not (so-called 'party disposition principle'), whereby this measure is under the Article 6 of the ECHR. However, few countries the UK, Portugal, Denmark and the Netherlands) have adopted 'opt-out' measure, whereby victims are deemed included in the action unless someone declares himself or herself not to be involved. A second feature concerns legal standing for the entities that might be allowed to start a collective action. ${ }^{37}$ In some

\footnotetext{
${ }^{35}$ Buccirossi and Carpagnano (n 25), 4 .

${ }^{36}$ Lear Study, 'Collective Redress in Antitrust', Study for the European Parliament DG Internal Policies department A $<$ http:/www.learlab.com/EN/publications.html $>\quad$ or $\quad<$ http://www.europarl. europa.eu/committees/en/studies.html $>$ accessed 22 February 20I/.

${ }^{37}$ Under the Commission Recommendation 2013/396/EU (n 2), the Member States should designate representative entities to bring representative actions on the basis of clearly defined conditions of eligibility. These conditions should include at least the following requirements: (a) the entity should have a non-profit making character; (b) there should be a direct relationship between the main objectives of the entity and the rights granted under Union law that are claimed to have been violated in respect of which the action is brought; and $(\mathbf{c})$ the entity should have
} 
countries group actions can be commenced by public authorities, for instance in Finland (Ombudsman) and Hungary (Hungarian Competition Authority), whilst in other jurisdictions, such as France, Sweden and Greece, representation is provided by national private organizations, such as consumer associations. Other countries have legal standing for a combination of a mixed approach: private organizations and harmed persons (Bulgaria, Italy, Spain, and the UK), public authorities and associations (eg the Netherlands). A third option involves funding of legal costs that may affect the ability and the incentives of claimants to initiate collective actions. A potential solution concerns the availability of contingency and conditional fees. This mechanism represents the American solution to the funding problem. Under this mechanism, the necessary means of funding are well ensured because client pays contingent fees to a lawyer only if there is a favourable result. However, it is equally true that contingency fees bring incentives for unmeritorious claims. Despite this fact, contingency fees have increased its popularity, utilized in some fashion in 12 out of 27 Member States (even if not in a pure US version) and now form permit arrangements between some claimants and their lawyers on the basis of some form of success fee. ${ }^{38}$ England and Wales, for instance, have adopted conditional fee arrangements under which lawyers can obtain a success fee in addition to the initial legal fee, which is usually around $25-50 \%$ of an awarded judgment if they win. ${ }^{39}$ Lawyers do not get anything if they lose and only get a normal fee indexed on the hourly billing plus a success fee which cannot exceed the normal fee. These conditional fees are linked to an 'after-the-event insurance', which would pay the adversarial party's costs in the event of losing the case. Another solution includes third-party funding (a company, bank or hedge fund), which could pay all or a part of the costs of an action in

sufficient capacity in terms of financial resources, human resources, and legal expertise, to represent multiple claimants acting in their best interest.

${ }^{38}$ Buccirossi and Carpagnano (n 25), 6.

${ }^{39}$ CEPS, EUR and LUISS, 'Making Antitrust Damages Actions More Effective in the EU: Welfare Impact and Potential Scenarios', Report for the European Commission DG COMP/2006/A3/or2, Final Report, Brussels, Rome and Rotterdam, $208<$ http://ec.europa.eu/competition/antitrust/actionsdamages/files_white_paper/impact_st udy.pdf $>$ accessed I/4 July 20r/. Recent reports in the UK support the need for an effective funding mechanism for litigation. For further debate on this topic, see further the recent report 'Review of Expenses and Funding of Civil Litigation in Scotland' (2013)<http://scotland.gov.uk/About/Review/taylor-review/Report $>$ accessed I5 July 2014. 
exchange to retain a share of a successful claims. ${ }^{40}$ In England and Wales, external financial options are being offered by diverse investors. In 20I2, there were ten active dedicated TPLF investors operating in the U.K., with three additional investors, Juridica, Burford, and IMF, making occasional investments. Most funders operating in the U.K. are relatively new, with the exception of Allianz, which has been funding claims since $2002 .^{4^{1}}$

\section{Assessment: OPT-IN vs OPT-OUT}

The European Commission recommends that collective redress in the EU should be based on the opt-in model, while the opt-out should be 'justified by reasons of sound administration of justice'.4 According to the Commission, the opt-in measure should be preferred because it:

- limits the risk of abusive litigation and unmeritorious claims;

- $\quad$ preserves the principle of party disposition; and

- $\quad$ guarantees that the judgment will not bind other potentially qualified claimants who did not join.

On the other hand, the opt-in measure tends to result in a low participation rate because the victims must express their wish to join the collective action, thus requiring them to spend time and money to start and develop the case. As such, it is unlikely that all victims will participate in collective action under the opt-in measure; as such, the compensatory objective is not achieved effectively. Several cases in national jurisdictions regarding the experiences of consumer organisations clearly indicate that opt-in collective actions are practically unworkable. Taking the example of the UK, the Replica Football Shirts case ${ }^{43}$ demonstrates the reluctance of consumers to take part in opt-in proceedings. The consumer association (Which?) brought an action in the collective interest of consumers who overpaid for football shirts due to a price-fixing cartel. Despite its efforts, Which?

\footnotetext{
$4^{\circ}$ Leskinen (n 29), $9^{5-96 .}$

4I C Veljanovski, 'Third-Party Litigation Funding in Europe' (2012) 8(3) J of L, Economics \& Policy, 410-413.

${ }^{2}$ E European Commission Recommendation 2013/396/EU (n 2); Articles 2I-25 stress the need to form claimant party by 'opt-in' principle.

${ }^{43}$ Case No ro78/7/9/o 7 Consumers Association v. JJB Sports Plc [2009] CAT 2.
} 
managed to collect claims for only 600 consumers, which was considered a very low proportion of victims who suffered harm by the anti-competitive behavior. After this failure, Which? announced they would not take part in collective actions in the future if it is based on the opt-in measure. In France, the finding of a price-fixing agreement among three mobile operators (Orange France, SFR, and Bouygues Telecom) had a potentially negative impact on 20 million consumers. ${ }^{44}$ However, consumer association UFC Que Choisir only managed to collect claims for 12,350 consumers. Hence, in countries where consumer associations have standing to bring damages claims, an opt-in model seems to be inappropriate to ensure sufficient participation rate for victims, in particular for cases involving multiple claims of low value (such as the harm caused by price fixing). In addition, in large-scale cartel agreements it is impossible in practice to get the consent of all harmed consumers, in particular when consumers cannot be easily identified. Due to low participation rate, consumer organizations pose a considerable obstacle of limited financial resources, thus limiting themselves to bringing damages actions due to uncertain financial perspective.

In such circumstances, this paper argues that opt-out collective actions are better suited to tackle the issues related with low participation rates, lack of funding and sub-optimal deterrence. In the first place, an optout scheme generally ensures that the group of claimants will be sufficiently large since the action is brought on behalf of the whole group, unless someone declares not to be involved. Taking the example of the US, an average opt-out rate is very low (less than $0.2 \%$ ) in consumer class actions, since in any case these claims cannot be litigated individually. ${ }^{45}$ In other words, opt-out collective actions increase access to justice, in particular for consumers involved in multiple claims of low value. It must be added, however, that the ones who are likely to opt-out are large companies or the individuals who have suffered significant harm. In addition, if the consumer association

${ }^{4} \mathrm{C}$ Hodges, The Reform of Class and Representative Actions in European Legal Systems. A New Framework for Collective Redress in Europe (Hart Publishing 2008), 84.

${ }^{45}$ For further discussion on opt-out rates, see T Eisenberg and G Miller, 'The Role of Opt-outs and Objectors in Class Action Litigation: Theoretical and Empirical Issues' (2004) New York University Law and Economics Research Paper No. 04-oo4; S Issacharoff, 'Preclusion, Due Process and the Right to Opt-out' (2002) 77 Notre Dame L Rev 105̆7, г60. 
is designated and membership fees are used for financing litigation, the budget of the action depends on the members' willingness to pay fees. The members are required to be a part of the consumer association and to pay membership fees to receive damages. As such, an opt-out model seems to be a more realistic alternative to ensure the action for damages financially viable due to a larger group of claimant willing to pay fees.

Furthermore, the preference given to opt-out schemes are likely to score better in terms of deterrence. As it is clear, the deterrence of collective redress depends on the size of the group of victims. If only a limited number of victims joined the proceedings, the deterrence will remain sub-optimal. Since the group of victims is larger under the opt-out measure, the size of the sanction expected under an opt-out system will be larger than under an opt-in system. As such, collective redress actions, based on an opt-out measure, can more effectively influence the potential companies' willingness to violate competition rules in the future. But if a company has already become part of a cartel, it can influence their tactics and negotiations as well as the amounts to be obtained in a settled action. ${ }^{6}{ }^{6}$ Whatever approach is taken, this paper argues that giving the right to consumer associations to claim damages on behalf of end-consumers gives impetus for the substantial deterrent effect. The potential cartelist will know that he might face private actions from consumers and the expected cost of the infringement will increase, and this combination of factors might act as an incentive for cartelists to contemplate twice before violating the competition rules.

Despite the positive aspects, opt-out proceedings also have two potential disadvantages. First, this measure might jeopardize the right of access to the courts under Article 6 of the European Convention for Human Rights (ECHR). ${ }^{47}$ Second, the opt-out measure may increase the number

${ }^{46}$ DL Tzakas, 'Effective Collective Redress in Antitrust and Consumer Protection Matters: a Panacea or a Chimera?' (2011) 48 Common Market L Rev, n36; R Korobkin and C Guthrie, 'Psychological Barriers to Litigation Settlement: an Experimental Approach' (1994) 93 Michigan L Rev, I07.

47 Article 6 para. I ECHR establishes that in the determination of his civil rights and obligations or of any criminal charge against him, everyone is entitled to a fair and public hearing within a reasonable time by an independent and impartial tribunal established by law'. On the contrary, the opt-out mechanism requires that a deliberate action is taken to withdraw from a judicial action. Therefore uninformed people may find themselves bound by a judgment they did not even know was about to be issued. For further discussion, see Lear Study (n 36). 
of unmeritorious claims. For these reasons, the introduction of an EUstyle collective redress mechanism could also be combined with the flexible hybrid of the opt-in/opt-out systems. The inspiration might be drawn from the examples of the UK and from the Danish model. In 20I4, The Consumer Right Bill ${ }^{48}$ extended the jurisdiction of the Competition Appeal Tribunal (CAT) in the UK. First and foremost, the CAT has exclusive jurisdiction to determine whether a collective action should proceed on an opt-out or opt-in basis. ${ }^{49}$ Second, the CAT is permitted to authorize a person or entity to commence collective actions regardless of being a public or a specified body. However, opt-out collective actions are not permitted to be brought by law firms. Another innovative provision is that the Bill established a collective settlement procedure in the CAT which encourages settlements. ${ }^{\text {5o }}$ If the settlement is reached, it has a binding effect on consumers, unless they opt-out. Besides the UK, another inspirational example of an opt-out class action system includes the one in Denmark. Opt-in group actions can be brought either by individual claimants, by any representative organization or by the Consumer Ombudsman. However, the judge may be granted, on a case-by-case basis, the discretion as to whether the optout model is necessary to guarantee that a significant proportion of injured parties are compensated for the damages suffered. ${ }^{\text {I } ~}$ The Danish

\footnotetext{
${ }^{48}$ Consumer Rights Bill (HC Bill 29), Second reading - the general debate on all aspects of the Bill - took place on I July. This stage is a formality that signals the start of the Bill's journey through the Lords. The Bill aims to make consumers better informed and better protected when they're buying. Online version is available here: $<$ www.publications.parliament.uk/pa/bills/lbill/20I/-20I5/o029/lbill_20I420150029_en_i.htm.> The law is stated as 7 July 20r4.

49 Schedule 8, para 5 of the Consumer Rights Bill (HC Bill 29). The Competition Appeals Tribunal (CAT) can already hear opt-in collective actions under the existing section $47 \mathrm{~B}$ of the Competition Act ${ }_{199} 8$ (CA 98 ). Paragraph 5 of the Consumer Rights Bill replaces section ${ }_{47} \mathrm{~B}$ of the Competition Act ${ }_{199}^{8}$ so as to provide space for opt-out collective proceedings, as well as continuing to provide for opt-in collective proceedings.

5o The function of a collective settlement regime is to introduce a procedure for infringements of competition law, where those who have suffered a loss and the alleged infringer may jointly apply to the CAT to approve the settlement of a dispute on an opt-out basis. The collective settlement regime will operate on the same opt-out principles as the opt-out collective proceedings.

${ }^{5}$ The Danish Administration of Justice Act (2007). For further discussion, see E Werlauff, Class Actions in Denmark, (2009) 622 Annals of the American Academy of Political \& Social Science 202. Opt-out class actions are only permitted as an exception to the main rule stipulated in Section $254 \mathrm{e}$, subsection 5 of The Administration of Justice Act: I) the constituent claims must be so small that they are
} 
rules prescribe that only a public authority (the Consumer Ombudsman) can take opt-out cases to court..$^{22}$ In the light of these statements, it is argued that the EU-style collective redress should be formed on the optout basis or at least on the hybrid of opt-out/opt-in, while the pure optin measure should be avoided.

\section{Legal Framework for Opt-Out Collective Redress in Antitrust}

Bearing in mind the diversity of national antitrust rules, opt-out (or hybrid of opt-out/opt-in) collective actions should apply at national level that follow the same basic principles throughout the EU, taking into account the legal traditions of the Member States and safeguarding against abuse. Contrary to the Recommendation on collective redress, this paper argues that a sector-specific measure should be adopted for collective redress in antitrust. A sector-specific measure ensures better uniformity among the Member States in relation to Articles Ior and Io2 TFEU. The critical idea underlying the horizontal initiative is that this mechanism requires further sector-specific implementation in national jurisdictions (in antitrust matters, for example, access to evidence, passing on and interaction between public and private enforcement of EU antitrust rules). With reference to a collective redress mechanism, a more suitable legislative act for a sector-specific initiative in EU competition law would be a directive rather than a regulation. A sectorspecific mechanism laid down in a directive would comply with the

unlikely to be brought as individual actions because the risk or cost of litigation is disproportionate to the size of the individual claims; 2) the court must deem an opt-in structure to be unfit for the action at hand. If the conditions are met, then the Administration of Justice Act Section 254 e, subsection 8 grants the possibility of using the opt-out mechanism. The legislative history indicates that the number of opt-out cases was expected to be very limited, and practice to date in Denmark has also shown this prediction to be correct. The major case, against Bank Trelleborg Sagerne 356/20IO og 28/20II (online version in Danish is available here: http:/www.domstol.dk/hojesteret/nyheder/Afgorelser/Pages/DomibankTrelleborggruppesgsmlet.aspx) failed in the Supreme Court after several years. It was thus emphasized that it must be clear that the claims would not otherwise be pursued, and they must be of modest size, as noted, less than 2,ooo kroner.

${ }^{52}$ Cf. Section $28(\mathrm{I})$ of the Marketing Practices Act, under which, if a majority of consumers have the same claim for compensation in connection with a breach of the Marketing Practices Act, the consumer ombudsman can, on request, group the claims under one. Section $28(2)$ provides that the ombudsman can be appointed group representative in a class action lawsuit (cf. Ch. 23a of the Administration of Justice Act). 
principles of subsidiarity and proportionality and it would be more respectful for national procedural autonomy. A directive, furthermore, would be a flexible instrument for introducing a minimum standard in any area of national law and avoid intervention in domestic provisions. This is of particular importance for the functioning of damages actions, ensuring common minimum guarantees all across the EU while leaving to the Member States the choice of the most appropriate tools to do so. ${ }^{53}$ In view of the chosen instrument for the Directive on damages actions, it would be more appropriate to stick to the same form of instrument towards a coherent European approach to collective redress. Furthermore, given the fact that collective redress is a highly debatable and sensitive topic at the EU and national level, a regulation seems one step too far, because it might interfere with domestic systems. From a technical point of view, the Article ro3 TFEU appears to be the most suitable Treaty provision with the CJEU case law in antitrust that requires that every legislative act should be based on one single legal basis. ${ }^{54}$ Also a legislative initiative under Article Io3 TFEU (besides antitrust specificities) would pave the legal background for both crossborder and national litigation, while the positive effects would also extend to both SMEs and consumers. Needless to say, a dual legal basis consisting of Articles ro3 and II/ TFEU could also be an alternative in antitrust collective redress. On deeper consideration, however, the interface between these provisions might be incompatible between the ordinary legislative procedure provided for by Article II4 TFEU and the special legislative procedure provided for by Article so3 TFEU.

\section{Collective Redress as a Potential Remedy to Mitigate DEFICIENCIES OF EU COMPETITION LAW ENFORCEMENT}

In the following section, it is demonstrated that collective redress is a potential remedy to mitigate deficiencies of competition law enforcement, including but not limited to: i) access to justice; ii) proving causation; and iii) insufficient public enforcement of EU competition law.

First, the availability of collective actions in national legal systems may facilitate access to justice by creating measures which simplify and help

\footnotetext{
${ }^{53}$ Lear Study (n 36); Buccirossi and Carpagnano (n 25) 8-9.

${ }^{54}$ See for instance, Case C- 242/87 Commission v. Council (ERASMUS) [1989] ECR 1425 .
} 
access to the courts. Collective actions would ensure a fundamental right for victims, namely in that legal representation is provided for a group of victims in order to ensure equality of arms. ${ }^{55}$ This is notably because of the potential to reduce the organizational costs and to handle the financial risks attached to private litigation. The costs of the lawsuit decrease because the financial risk is spread over a group of injured persons participating in the collective procedure. It means that plaintiffs no longer run the risk of having to bear extensive costs of the lawsuit. Furthermore, the probability of winning the case increases since multiple plaintiffs have larger financial means to pay for experienced and highly competent lawyers in the relevant fields of law, while individual consumers may not be able to afford on representatives with such a level of expertise. ${ }^{56}$

Second, collective redress provides an attractive ability to bundle multiple individual claims and thus to gain efficiencies by tackling common legal, factual and economic issues collectively (and giving the claimants more clout against the defendants). In cases where an authorized consumer association files a claim on behalf of its members, it might reverse the insurmountable burden of proof from the plaintiff to their own hands. ${ }^{57}$ It is clear that consumer associations have larger financial means to start and develop antitrust cases, for example, to cover legal fees and potential expert fees. Furthermore, the availability of representative actions could greatly solve, or at least diminish, information asymmetry, meaning that plaintiffs are in a better position to provide proof with sufficiently high probability. Therefore, representative action by a consumer association may have the informational advantages of the applicable laws in comparison with individual consumers, such that designated bodies are able to assess better whether certain behaviour of firms constitutes an infringement. ${ }^{58}$ In addition, it is argued that consumer associations may facilitate the analysis of the but-for test. In order to conduct such an analysis, the

\footnotetext{
55 See, for instance, Case C-305/05 Ordre des barreaux francophones et germanophone and others o Conseil des ministers [2007] ECR I-53o5, [3I]. The European Court of Justice ruled that the right to be represented by a lawyer is indispensable for a fair civil proceeding according to Article 6 of the European Human Rights Convention.

${ }^{56} \mathrm{R}$ Van den Bergh and L Visscher, "The Preventive Function of Collective Actions' (2008) i Erasmus L Rev 2, I9.

${ }^{57}$ Abele, Kodek, Schaefer (n i9), 85ı.

${ }^{58}$ Van den Bergh and Visscher (n 56), I9.
} 
claimant has to have thorough understanding of the relationship between prices and their determinants, including the potential impact of the antitrust violation. ${ }^{59}$ It is clear that the complexity of methods and models for assessing the but-for test might be too complicated for private parties, especially for consumers. As such, collective actions are attractive alternative to determine the real damage value as closely as possible which that is embedded in the full-compensation principle.

Third, collective redress is a potential tool to mitigate dysfunctional compensatory mechanisms of EU competition law. It should be observed that public authorities alone are not able to enforce competition law effectively because they lack resources and competence to secure compensations for victims. As mentioned before, truly effective compensation by the way of private enforcement is limited, because private parties face significant obstacles in bringing damages actions. In such circumstances, the collective redress mechanism seems a useful aid to antitrust enforcement through creating the enlarged group of enforcers able to claim their rights granted under EU law. Moreover, if a collective redress mechanism is established, then it has to increase the part played by national competition authorities and national courts in implementing EU and national competition law while guaranteeing its effective and uniform application. Finally, the collective redress approach also involves the matter of antitrust enforcement between the Member States. The common collective redress would facilitate inter-European antitrust enforcement in three different ways:

I. Claimants in one Member State are able to access redress mechanisms in other Member States when they have suffered a detriment.

2. Claimants are provided with clear and predictable means of recognizing and enforcing judgments from other Member States.

3. Likewise, representative bodies based in one Member State are able to take or facilitate action on behalf of affected claimants in another Member State.

This envisages the consumer protection against rogue traders across the borders since consumer bodies and national enforcement authorities would be built upon judicial cooperation between different Member

${ }^{59}$ Abele, Kodek, Schaefer (n 19), 854. 
States. $^{60}$ If such a system were to be developed, the cases with cross border elements would be easier resolved.

\section{Conclusion}

The current orientation of public antitrust authorities is to stress deterrence when imposing cartel fines. Even at their unprecedented high level, current antitrust fines against cartels seem to be insufficient to ensure deterrence. First, the increasing number of discovered cartels and increasing fines show that the existing fines may not be enough to persuade cartelists to abide the law. Second, recent law and economics literature estimates that the gain from collusion outweighs the expected punishments, even given the upper limits of a possible fine and the probability of detection in calculating the deterrence of antitrust fines. As such, it was argued that current fine levels should be complemented with other measures to enhance deterrence, in particular a more deterrence-oriented private enforcement. However, in as much as private enforcement framed upon competition law, it serves primarily a compensation function while deterrence is viewed as a welcome sideeffect. From this perspective, this paper observed three main obstacles facing victims of competition law infringements in bringing damages actions: (i) cost and (legal) uncertainty; (ii) complexity of causality; and (iii) disclosure rules. Collective redress mechanisms appeared to be an attractive alternative to solve, or at least diminish, the inefficiencies of antitrust enforcement: sub-optimal deterrence and ineffective damages claims. Nevertheless, the effectiveness of collective claim depends on the type of collective actions introduced and whether it provides sufficient incentives to bring collective action and possibilities for funding.

First, it was observed that opt-in collective actions are practically not workable in national jurisdictions. In such circumstances, this paper argued that an opt-out nature of collective action is better suited to tackle the issues related with low participation rates, lack of funding and sub-optimal deterrence. However, opt-out proceedings, at least in the

\footnotetext{
6o The Law Society of England and Wales, 'Towards a Coherent European Approach to Collective Redress' (201I) ETI Registration number: 24II8I93II7-34, I3; 'Cooperation between Member States for Consumer Protection' (Europa Website) $<$ http://europa.eu/legislation_summaries/consumers/protection_of_consumers/132o 47_en.htm> accessed i5 April 20ı4.
} 
Commission's expectations, might jeopardize the right of access to the courts under Article 6 of the ECHR and might increase the number of unmeritorious claims. In the light of these statements, it was argued that the EU-style collective redress should be based primarily on the opt-out basis or at least on the hybrid of opt-out/opt-in, while the pure opt-in measure should be avoided.

Second, as regards the deficiencies of private enforcement by individual parties, it was demonstrated that collective actions in national legal systems may therefore facilitate access to justice by creating measures which simplify and help access to the courts. Furthermore, collective redress provides an attractive vehicle to deal with a wide range of legal and economic methods for proving causation. In cases where an authorized consumer association files a claim on behalf of its members, it might reverse the insurmountable burden of proof from the plaintiff to their own hands. Finally, collective redress is an effective tool to mitigate dysfunctional enforcement by public authorities. This is remarkably because the collective redress mechanism is a useful aid to public enforcement through creating the enlarged group of enforcers able to claim their rights granted under EU law.

Given the possible attractiveness of opt-out collective actions, the binding collective redress procedures in antitrust has to be included in the legal framework of EU competition law. Opt-out collective actions applying at national levels should follow the same basic principles throughout the EU for the sake of consistency across the EU. Contrary to the Recommendation on collective redress, this paper argues that a sector-specific measure should be adopted for collective redress in antitrust. From this perspective, a more effective legislative act for a sector-specific initiative in EU competition law would be a regulation rather than a directive. From a technical point of view, Article ro3 TFEU, which requires that every legislative act should be based on one single legal basis, appears to be the Treaty provision that is most compatible with the CJEU case law in the field of antitrust. According to the plan of a package on private damages actions, the Member States have to put in place the principles set out in the Recommendation by June 20I5. After that, the Commission will assess the impact of its Recommendation, and based on the results of this, decide whether further measures are necessary. The binding measure on collective redress is expected in 2017. For these reasons, it will be interesting to 
follow the recent developments in the UK, where a limited opt-out provision into the collective action regime is going to be introduced together with the Consumer Rights Bill in 20r4. If it can work effectively without abusive litigation, this approach could inspire the Commission for a more assertive approach on collective redress. 